\title{
5-O-Acetyl-Renieramycin T from Blue Sponge Xestospongia sp. Induces Lung Cancer Stem Cell Apoptosis
}

\author{
Wipa Chantarawong ${ }^{1,2}$, Supakarn Chamni ${ }^{3} \mathbb{D}$, Khanit Suwanborirux ${ }^{3}$, Naoki Saito ${ }^{4}$ (D) and \\ Pithi Chanvorachote $1,2, *$ (D) \\ 1 Cell-based Drug and Health Products Development Research Unit, Chulalongkorn University, \\ Bangkok 10330, Thailand; chantarawong.wp@gmail.com \\ 2 Department of Pharmacology and Physiology, Faculty of Pharmaceutical Sciences, \\ Chulalongkorn University, Bangkok 10330, Thailand \\ 3 Department of Pharmacognosy and Pharmaceutical Botany, Faculty of Pharmaceutical Sciences, \\ Chulalongkorn University, Bangkok 10330, Thailand; supakarn.c@pharm.chula.ac.th (S.C.); \\ Khanit.S@chula.ac.th (K.S.) \\ 4 Graduate School of Pharmaceutical Sciences, Meiji Pharmaceutical University, 2-522-1 Noshio, Kiyose, \\ Tokyo 204-8588, Japan; naoki@my-pharm.ac.jp \\ * Correspondence: pithi_chan@yahoo.com; Tel.: +662-2188-344
}

Received: 14 January 2019; Accepted: 7 February 2019; Published: 11 February 2019

check for updates

\begin{abstract}
Lung cancer is one of the most significant cancers as it accounts for almost 1 in 5 cancer deaths worldwide, with an increasing incident rate. Management of the cancer has been shown to frequently fail due to the ability of the cancer cells to resist therapy as well as metastasis. Recent evidence has suggested that the poor response to the current treatment drugs and the ability to undergo metastasis are driven by cancer stem cells (CSCs) within the tumor. The discovery of novel compounds able to suppress CSCs and sensitize the chemotherapeutic response could be beneficial to the improvement of clinical outcomes. Herein, we report for the first time that 5-O-acetyl-renieramycin $\mathrm{T}$ isolated from the blue sponge Xestospongia sp. mediated lung cancer cell death via the induction of p53-dependent apoptosis. Importantly, 5-O-acetyl-renieramycin $\mathrm{T}$ induced the death of CSCs as represented by the CSC markers CD44 and CD133, while the stem cell transcription factor Nanog was also found to be dramatically decreased in 5-O-acetyl-renieramycin T-treated cells. We also found that such a CSC suppression was due to the ability of the compound to deplete the protein kinase B (AKT) signal. Furthermore, 5-O-acetyl-renieramycin T was able to significantly sensitize cisplatin-mediated apoptosis in the lung cancer cells. Together, the present research findings indicate that this promising compound from the marine sponge is a potential candidate for anti-cancer approaches.
\end{abstract}

Keywords: 5-O-acetyl-renieramycin T; Xestospongia sp.; cisplatin; lung cancer; anti-cancer; apoptosis

\section{Introduction}

The oceans have long been recognized as a potential source of marine organisms that may be capable of producing structurally unique and biologically active compounds. Due to the enormously diversified environments found in the oceans, marine organisms are indeed founts of novel candidates for drug discovery [1]. Approximately 63\% of new drugs currently being developed are related to natural products, including natural product-derived drugs, chemically-modified natural products, and synthetic compounds with a natural product as a pharmacophore. Over the period 1980-2008, about $60 \%$ of anti-cancer drugs were developed significantly from natural sources [2]. New concepts 
of cancer cell biology as well as cancer drug discovery are focused on a defined cancer type's specific molecular targets. Cancer stem cells (CSCs) are a specialized rare population of cells within tumors that possess self-renewal, differentiation, and tumor forming abilities [3]. CSCs have also been shown to be a seed of cancer and a potentiating factor in cancer progression [4]. Emerging evidence has confirmed the strong relevance of CSCs and their impact on clinical outcomes, as CSCs have been shown to be resistant to therapeutic drugs and are the cause of metastasis; for instance, one study reported that CSCs are responsible for cisplatin resistance in lung cancer [5]. Besides, in vitro and in vivo studies have shown that cisplatin treatment can enrich CSCs in non-small-cell lung carcinoma (NSCLC) [6-8]. In lung cancer, CSCs can be characterized by an increase in stem cell transcription factors and cellular surface markers, such as CD44 and CD133 [5,9]. CD133 (Prominin 1) is a cell surface glycoprotein that has been identified as an important molecular marker of stem-like cells. Recent research showed that CD133 expression is related to the levels of resistance-mediated proteins in patients with NSCLCs [10]. $\mathrm{CD}_{133^{+}}$cancer cells exhibit significant resistance to anti-tumor treatment, including chemotherapy [10]. A recent study indicated that cisplatin could increase the ratio of $\mathrm{CD}_{133^{+}}$cells in lung cancer [11]. Accumulating data point out the important role of the AKT signaling pathway in the tumorigenicity of CSCs [12]. It has been reported that AKT inhibitors could suppress the colony formation of CSCs, which suggests they might be potential agents for suppressing CSCs in cancer chemotherapy [13].

Renieramycins $\mathrm{A}-\mathrm{Y}$ are a series of tetrahydroisoquinoline marine alkaloids isolated from Xestospongia sp., which is a marine blue sponge found in the seas around Thailand and the Philippines [14-19]. These renieramycin derivatives contain the chemical structures and biological activities related to other isoquinoline natural products, such as naphthyridinomycins, quinocarcins, saframycins, and ecteinascidins [14], which exhibit diverse bioactivities, such as antitumor, antibacterial, antiviral, anticoagulant, anti-inflammatory, anti-Alzheimer, and anticonvulsant activities [20]. Among the renieramycins family, renieramycin T, a renieramycin-ecteinascidin hybrid marine natural product, has recently become an interesting target for synthetic and biological studies regarding a highly substituted phenol and a condensed 1,3-dioxole ring, which are similar to the left-hand-side carbon framework of those in ecteinascidins [21,22]. The addition of an acetyl group by esterification of the phenol moiety of renieramycin T furnishes 5-O-acetyl renieramycin T ( $O$-acetyl RT) (Figure 1), having an identical left-hand-sided structure to the U.S. Food and Drug Administration (FDA)-approved anti-cancer drug Ecteinascidin 743 (Yondelis ${ }^{\circledR}$ ) [23]. It has been reported that $\mathrm{O}$-acetyl RT and other renieramycins, such as renieramycin $\mathrm{M}$ and renieramycin $\mathrm{T}$, have a strong cytotoxicity, with inhibitory concentration $\left(\mathrm{IC}_{50}\right)$ values in the range of nanomolar concentrations against many human cancer cell lines, including colon cancer HCT116 and DLD1 cells, breast cancer MDA-MB-435 cells, pancreatic cancer AsPC1 cells, lung carcinoma QC56 cells, and non-small-cell lung cancer cells $[19,24,25]$. However, the effect of $O$-acetyl RT and its mechanism on human NSCLC has not yet been elucidated. Herein, we report that $O$-acetyl RT synthesized from renieramycin T induced apoptosis, suppressed CSCs, and sensitized NSCLC H292 cells to cisplatin. These findings might benefit the development and further investigation of this compound as a sensitizer of NSCLC to cisplatin. 


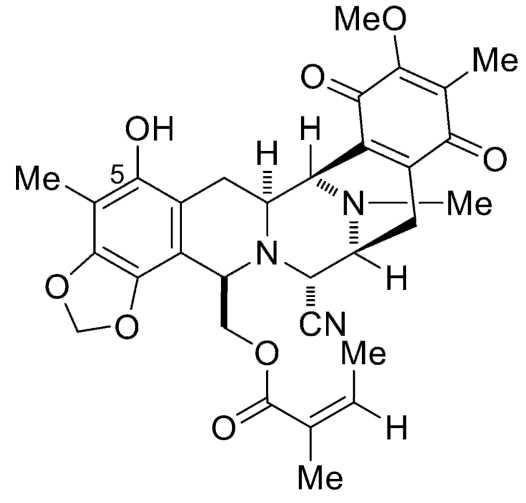

renieramycin $\mathrm{T}$

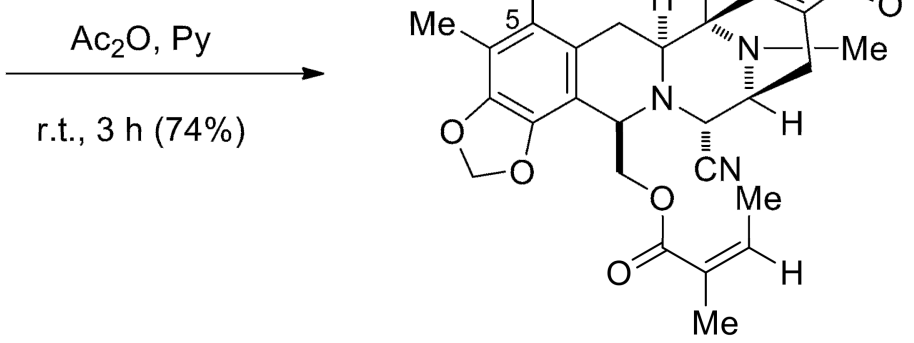

5-O-acetyl-renieramycin T

Figure 1. The synthesis of 5-O-acetyl-renieramycin T.

\section{Results}

2.1. O-Acetyl RT Reduced the Cell Viability and Induced the Apoptosis of Non-Small-Cell Lung Carcinoma (NSCLC) Cells

Before the sensitizing effect of $O$-acetyl RT on cisplatin-mediated cancer cell death was determined, we investigated the cytotoxic profile of $O$-acetyl RT compared with doxorubicin and cisplatin, the standard chemotherapeutic drugs for lung cancer therapy, using the MTT cell viability assay. Human lung cancer $\mathrm{H} 292$ cells were incubated with various concentrations $(0-25 \mu \mathrm{M})$ of compounds for $24 \mathrm{~h}$. The results showed that $O$-acetyl RT had a greater cytotoxic effect on H292 cells than that of doxorubicin and cisplatin (Figure 2A,B). O-acetyl RT was considered non-toxic at concentrations $\leq 0.05 \mu \mathrm{M}$ for H292 cells. Moreover, the cytotoxic effect of $\mathrm{O}$-acetyl RT was also assessed in A549 and H23 cells. The results showed that $O$-acetyl RT exhibited cancer-suppressing activity in a dose-dependent manner in all three of the NSCLC cell lines but was more effective in H292 cells (Figure 2B).

To determine whether the anti-cancer effect of $O$-acetyl RT was related to apoptosis, we treated H292 cells with O-acetyl RT $(0-25 \mu \mathrm{M})$ for $24 \mathrm{~h}$ and then quantified the apoptotic cells using the Hoechst 33342/propidium iodide (PI) double staining assay. We found that O-acetyl RT was able to induce apoptosis of H292 cells in a dose-dependent manner (Figure 2C). The result revealed the presence of apoptotic nuclei with condensed or fragmented nuclei in the cells treated with $O$-acetyl RT at concentrations $\geq 1 \mu \mathrm{M}$, whereas the number of apoptotic cells was not changed in cells treated with lower concentrations $(<1 \mu \mathrm{M})\left(F_{6,14}=386.32, p<0.0001\right)$. Moreover, necrosis cell death was not detected under all treatments. To confirm the apoptosis-inducing effect of $O$-acetyl RT, apoptotic cells were determined using the Annexin V/PI apoptosis assay. O-acetyl RT caused an increase in the number of early-apoptotic cells dependent on the treated concentrations (Figure 2D). As shown in Figure 2D, the percentage of early-apoptotic cells was $41.76 \%, 46.56 \%, 53.89 \%$, and $73.34 \%$ in the $\mathrm{H} 292$ cells treated with $O$-acetyl RT at concentrations of 1,5,10, and $25 \mu \mathrm{M}$, respectively. Together, these data indicate that $\mathrm{O}$-acetyl RT decreased cell viability and increased apoptotic cells in H292 cells. 


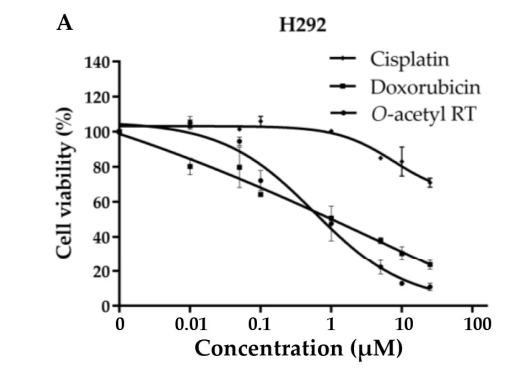

\begin{tabular}{lccc}
\hline \multirow{2}{*}{ Cells } & \multicolumn{3}{c}{$\mathrm{IC}_{50} \pm \mathrm{SD}(\mu \mathrm{M})$} \\
\cline { 2 - 4 } & O-acetyl RT & Doxorubicin & Cisplatin \\
\hline H292 & $0.66 \pm 0.26$ & $0.92 \pm 0.28$ & $46.50 \pm 0.21$ \\
A549 & $33.24 \pm 4.75$ & $7.28 \pm 1.61$ & $72.79 \pm 2.52$ \\
H23 & $33.77 \pm 2.22$ & $73.86 \pm 2.34$ & $76.17 \pm 0.40$ \\
\hline
\end{tabular}

C
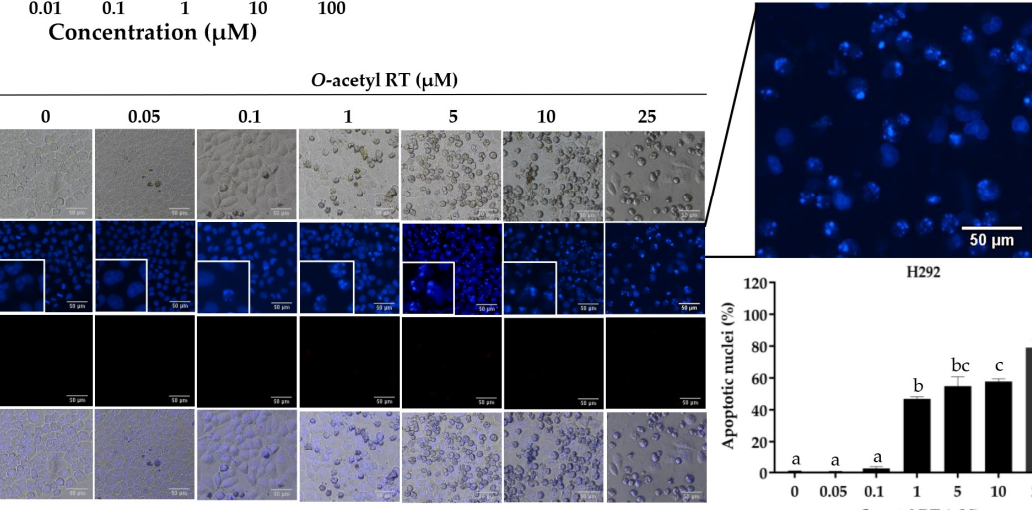

Hoechst33342

PI

Merge
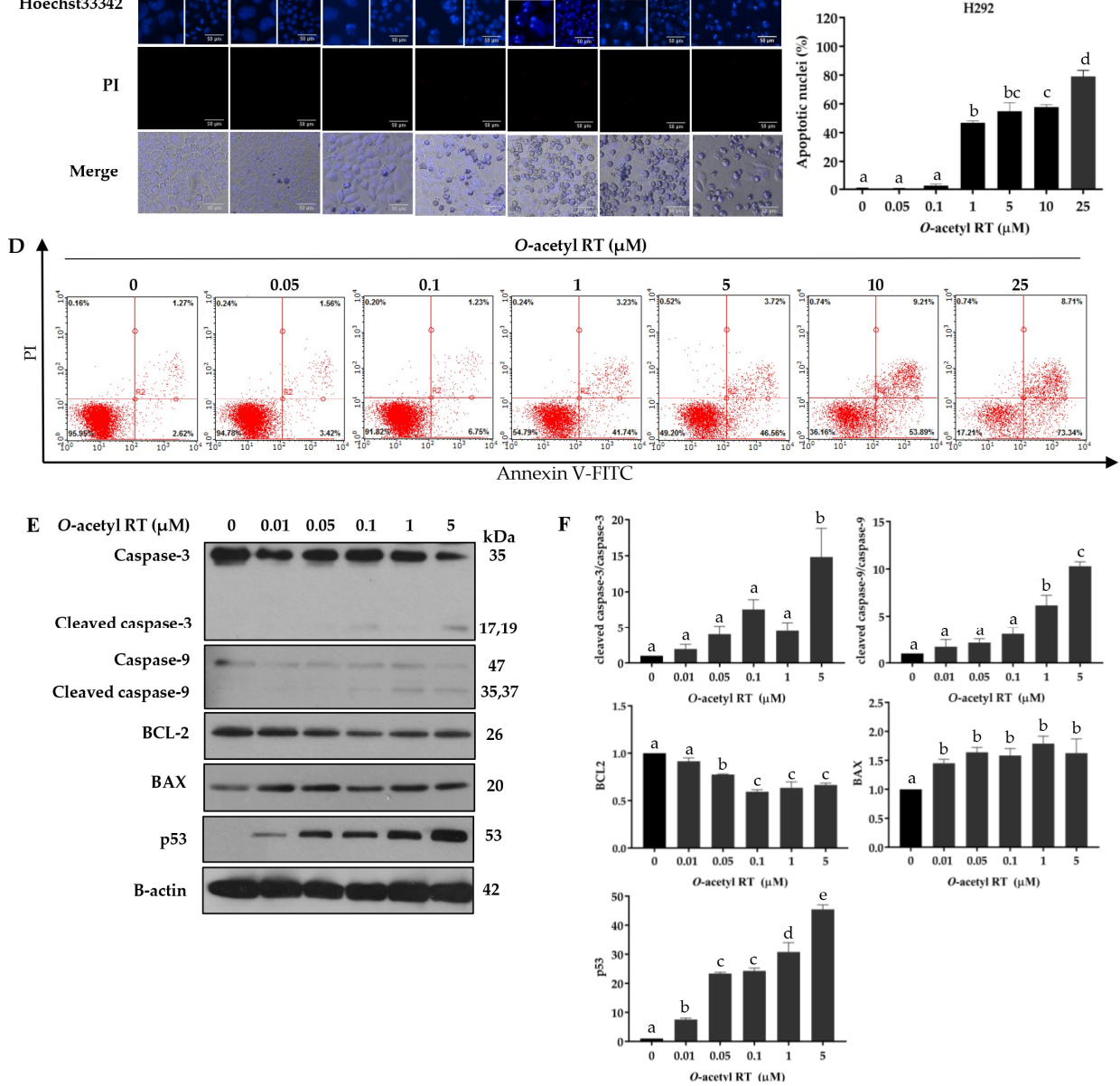

Figure 2. O-acetyl RT reduces cell viability and induces apoptosis in non-small-cell lung carcinoma (NSCLC) cells. (A) H292 cells were treated with various concentrations of $O$-acetyl RT, cisplatin, and doxorubicin $(0-25 \mu \mathrm{M})$ for $24 \mathrm{~h}$. Cell viability was determined by MTT assay. (B) The half-maximal inhibitory concentration $\left(\mathrm{IC}_{50}\right)$ of each cell line at $24 \mathrm{~h}$ was calculated. $(\mathrm{C})$ The nuclei of $\mathrm{H} 292$ cells treated with $\mathrm{O}$-acetyl RT were stained with Hoechst 33342 /propidium iodide (PI) and calculated as a percentage compared with nontreated control cells. (D) Apoptotic and necrotic cell death were determined using the Annexin V/PI staining assay. (E) The expression levels of apoptosis-associated proteins, caspase-3, cleaved caspase-3, caspase-9, cleaved caspase-9, BCL-2, BAX, and p53 proteins in H292 cells treated with $O$-acetyl RT $(0-5 \mu \mathrm{M})$ for $24 \mathrm{~h}$ were examined by Western blot analysis. To confirm equal loading of the protein samples, the blots were reprobed with the $\beta$-actin antibody. (F) Relative protein levels were quantified by densitometry. Data represent the mean \pm standard deviation (SD) $(n=3)$. Bars labeled with different letters $(\mathrm{a}, \mathrm{b}, \mathrm{c}, \mathrm{d}, \mathrm{e})$ are significantly different at $p<0.05$. 


\subsection{O-Acetyl RT Induced Apoptosis through p53 Activation}

Having shown the potential of apoptosis induction, we then confirmed the apoptosis effect of $O$-acetyl RT using specific apoptotic markers, including the activation of caspase- 3 and caspase- 9 . The cells were treated with $O$-acetyl RT $(0-5 \mu \mathrm{M})$. The key proteins controlling apoptosis were determined by Western blot analysis. As shown in Figure 2E,F, $5 \mu \mathrm{M}$ of $O$-acetyl RT significantly induced the activation of caspase- 3 compared to the non-treated cells $\left(F_{5,12}=14.63, p=0.0026\right)$. In agreement with such results, the expression of the active form of caspase- 9 was found to be significantly upregulated in $\mathrm{H} 292$ cells treated with $O$-acetyl RT at 1 and $5 \mu \mathrm{M}\left(F_{5,12}=57.63, p<0.0001\right)$.

We further evaluated the underlying mechanism of apoptosis induction by investigating the major regulators of p53-dependent apoptosis, such as BCL-2, BAX, and p53, which is one of the important mechanisms of anti-cancer drug action [26-28]. Furthermore, the BCL2 family proteins are important mediators for chemotherapeutic resistance $[29,30]$. Western blot analysis showed that there was an increase in the expression of $\operatorname{BAX}\left(F_{5,12}=9.021, p=0.0093\right)$ and p53 $\left(F_{5,12}=219, p<0.0001\right)$, and a decrease in the expression of BCL-2 $\left(F_{5,12}=51.31, p<0.0001\right)$ in O-acetyl RT-treated H292 cells compared to non-treated cells. (Figure 2E,F). Taken together, these results indicated that $O$-acetyl RT induces apoptosis via activating p53 as well as by suppressing the anti-apoptotic BCL2 protein and inducing the pro-apoptotic BAX protein in $\mathrm{H} 292$ cells.

\subsection{O-Acetyl RT Suppresses Cancer Stem Cell Signals in H292 Cells}

CSCs are known to be a driver of aggressive behaviors and poor prognosis in various cancers [22]. For lung cancer, the AKT pathway and its downstream signals have been frequently shown to contribute CSC phenotypes [12]. Therefore, we determined whether $O$-acetyl RT was able to suppress such CSC signals. Cells were treated or left untreated with the compound for $24 \mathrm{~h}$ and the levels of lung CSC marker CD44 and pluripotent transcription factor Nanog were determined by Western blot analysis. As shown in Figure 3A,B, O-acetyl RT at the concentrations $\geq 0.1$ and $\geq 0.05$ significantly decreased the cellular levels of $\operatorname{Nanog}\left(F_{5,12}=333.8, p<0.0001\right)$ and CD44 $\left(F_{5,12}=77.13, p<0.0001\right)$, respectively. In addition, this CSC-suppressing activity of the compound was supported by the depletion of CD133-positive $\left(\mathrm{CD} 133^{+}\right)$cells $\left(F_{5,12}=21.14, p<0.0001\right)$ in the $O$-acetyl RT-treated cells, as determined by flow cytometry (Figure $3 \mathrm{C}$ ). The corresponding upstream signals, including AKT, were monitored by Western blotting. We found that $O$-acetyl RT caused a reduction in active AKT $\left(F_{5,12}=15.27, p=0.0023\right)$ in H292 cells (Figure 3D,E). 

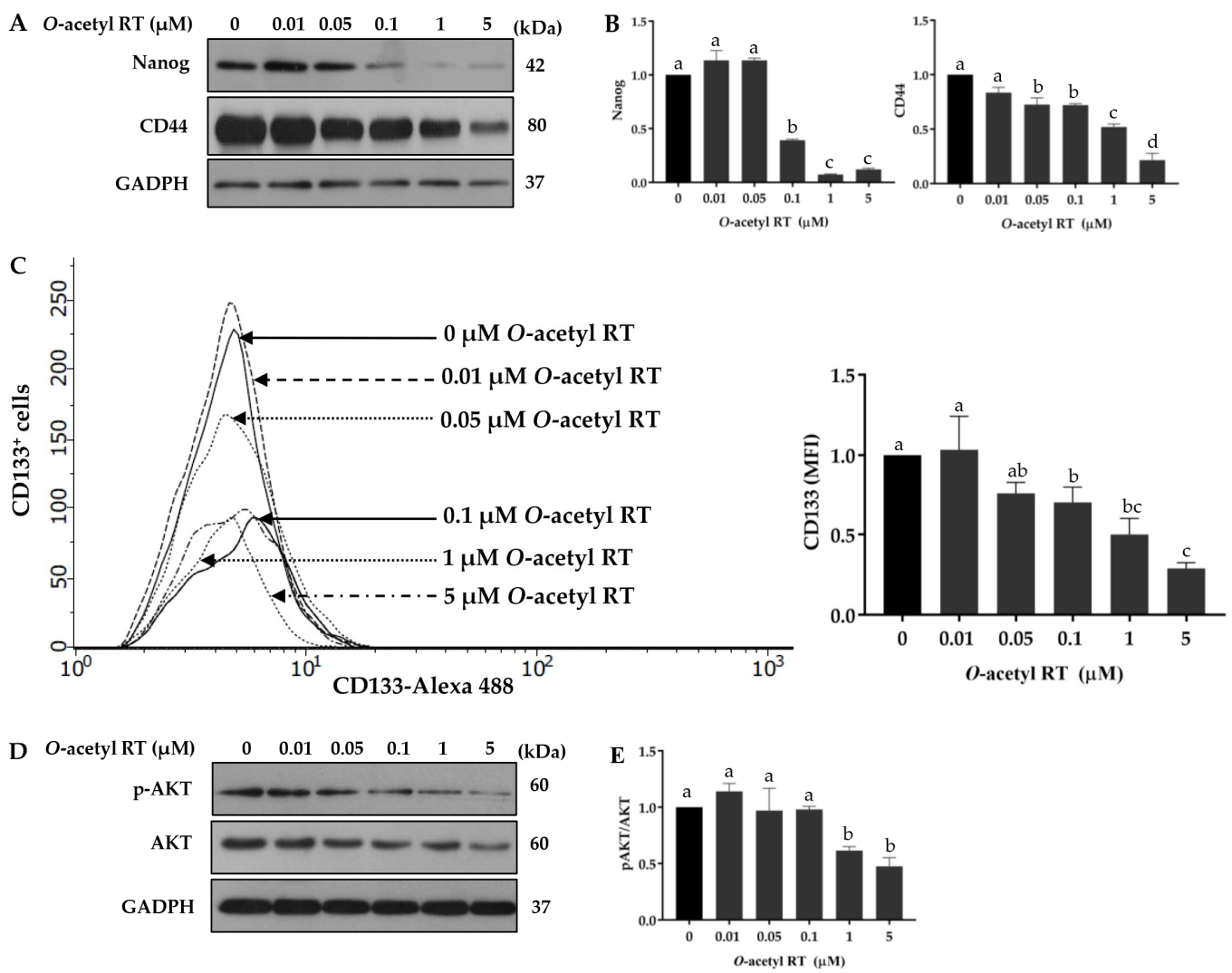

Figure 3. $O$-acetyl RT inhibits cancer stem cell signals. Cells were treated with $O$-acetyl RT $(0-5 \mu \mathrm{M})$ for $24 \mathrm{~h}$. The expression levels of cancer stem cell markers CD44 and Nanog in H292 cells were determined by Western blot analysis. (A) The blots were reprobed with the GADPH antibody. (B) Relative protein levels were determined by densitometry. (C) The $\mathrm{CD}_{133^{+}}$cells were determined by flow cytometry. (D) Cellular levels of activated AKT (p-AKT) and total AKT were examined by Western blot analysis. (E) The immunoblot signals were quantified by densitometry. Data represent the mean $\pm \operatorname{SD}(n=3)$. Bars labeled with different letters $(\mathrm{a}, \mathrm{b}, \mathrm{c}, \mathrm{d})$ are significantly different at $p<0.05$.

\subsection{O-Acetyl RT Increases Sensitivity of H292 Cells to Cisplatin}

To test whether $O$-acetyl RT could sensitize $\mathrm{H} 292$ cells to cisplatin, the cells were pretreated with non-toxic concentrations $(0.01$ or $0.05 \mu \mathrm{M})$ of $O$-acetyl RT for $24 \mathrm{~h}$, followed by treatment with $50 \mu \mathrm{M}$ cisplatin for $24 \mathrm{~h}$, and cell viability was measured using MTT assay. Figure 4A shows that the $\mathrm{H} 292$ cells were robustly sensitized to cisplatin by pretreatment with $0.05 \mu \mathrm{M} \mathrm{O}$-acetyl RT (Figure 4A) $\left(F_{5,12}=698.3, p<0.0001\right)$. The cell viability of $\mathrm{H} 292$ cells treated with cisplatin was reduced by $56 \%$, whereas a combination of 0.01 or $0.05 \mu \mathrm{M} O$-acetyl RT with cisplatin was more effective than cisplatin alone and reduced cell viability by $62 \%$ and $81 \%$, respectively. This effect was further confirmed using a colony formation assay (Figure $4 \mathrm{~B})\left(F_{5,12}=178, p<0.0001\right)$. Figure $4 \mathrm{C}$ also shows that the combination treatments of $0.05 \mu \mathrm{M} O$-acetyl RT and $50 \mu \mathrm{M}$ cisplatin significantly induced apoptosis compared to the group treated with cisplatin alone $\left(F_{5,12}=238.3, p<0.0001\right)$. Western blot analysis showed that the pretreatment of $0.05 \mu \mathrm{M} O$-acetyl RT significantly increased the expression of the active form of caspase-3 $\left(F_{3,8}=237.9, p<0.0001\right)$ and caspase-9 $\left(F_{3,8}=60.9, p=0.0009\right)$ (Figure $\left.4 \mathrm{D}, \mathrm{E}\right)$. Figure 4D,E also show that the level of the anti-apoptotic protein BCL-2 was significantly downregulated $\left(F_{3,8}=80.87\right.$, $p=0.0005)$ and pro-apoptotic protein BAX was significantly upregulated $\left(F_{3,8}=38, p=0.0021\right)$ in the $O$-acetyl RT pretreatment. Pretreatment with $0.05 \mu \mathrm{M} O$-acetyl RT could increase the expression of p53 $\left(F_{3,8}=41.83, p=0.0018\right)$ but the level of p53 expression was not altered in the $O$-acetyl RT pretreatment group when compared to the group treated with cisplatin alone $(p>0.9999)$. It has been reported that cisplatin can activate the ERK pathway leading to the induction of p53-dependent apoptosis in lung 
cancer cells [31]. In line with this, the results from Figure $4 \mathrm{~F}, \mathrm{G}$ show that pretreatment with $\mathrm{O}$-acetyl RT clearly increased the p-ERK level in H292 cells $\left(F_{3,8}=142.9, p<0.0002\right)$.

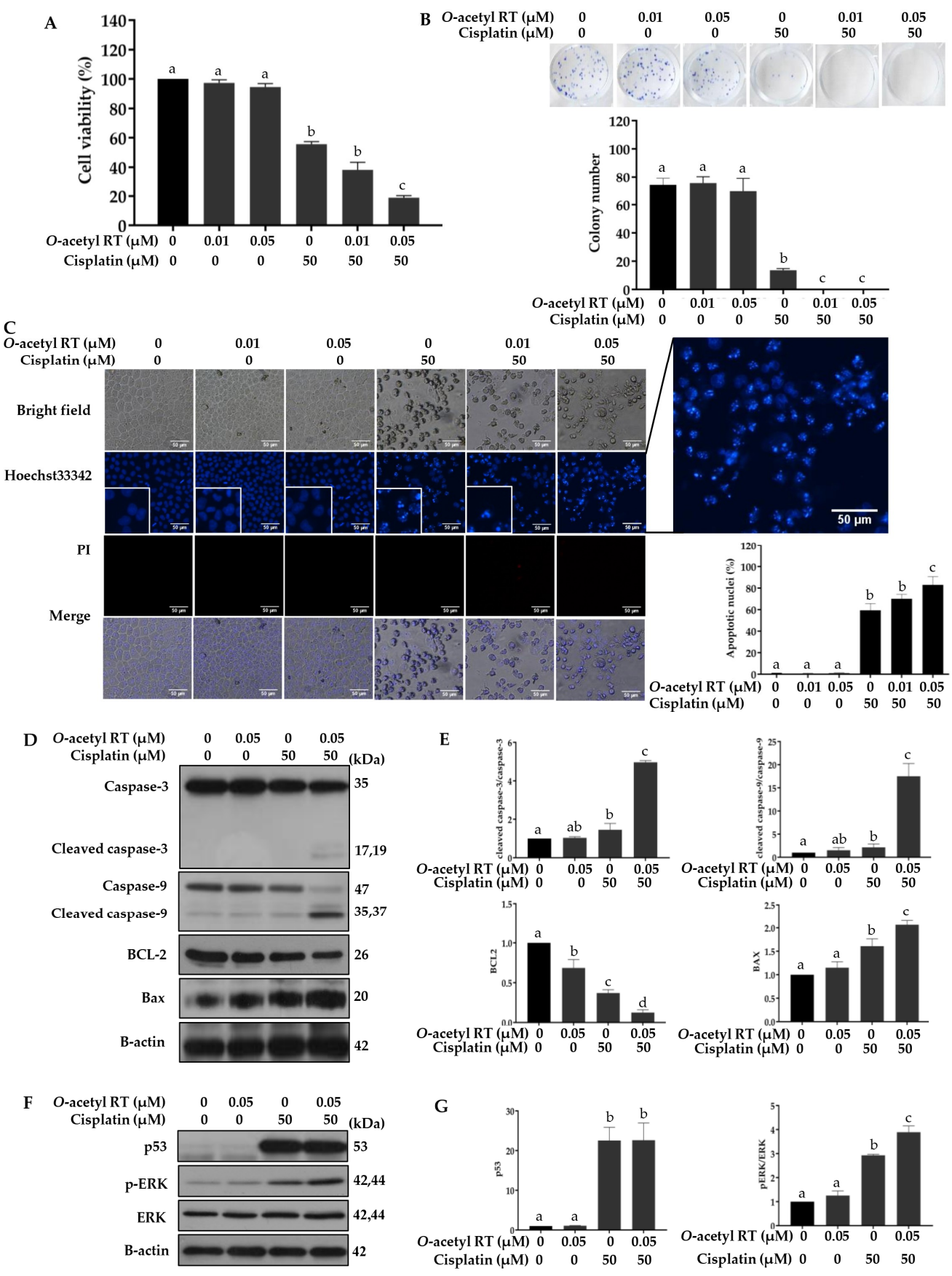

Figure 4. O-acetyl RT sensitizes H292 to cisplatin. (A) Cell viability of NSCLC H292 cells treated with 0.01 and $0.05 \mu \mathrm{M}$ of $O$-acetyl RT for $24 \mathrm{~h}$ prior to treatment with $50 \mu \mathrm{M}$ of cisplatin was determined using the MTT assay. (B) Effect of $O$-acetyl RT sensitization on cell growth of $\mathrm{H} 292$ cells was observed using a colony formation assay. (C) Hoechst 33342/PI double staining was used to determine cell apoptosis. (D) The expression levels of apoptosis-associated proteins in $\mathrm{H} 292$ cells treated with $0.05 \mu \mathrm{M}$ of $O$-acetyl RT for $24 \mathrm{~h}$ prior to treatment with $50 \mu \mathrm{M}$ of cisplatin were assessed by Western blotting, and (E) the relative expression was calculated using densitometry. (F) The expression levels of activated ERK (p-ERK), total ERK, and p53 were also examined using Western blotting, and (G) the relative expression was calculated using densitometry. Data represent the mean $\pm \operatorname{SD}(n=3)$. Bars labeled with different letters $(\mathrm{a}, \mathrm{b}, \mathrm{c}, \mathrm{d})$ are significantly different at $p<0.05$. 


\subsection{O-Acetyl RT Reduces Cisplatin-Induced CD133+ Cells Subpopulation in H292 Cells}

We further observed the inhibition of cisplatin-induced stemness with $O$-acetyl RT sensitization. The spheroid number and area of the group pretreated with $O$-acetyl RT, following by treatment with $50 \mu \mathrm{M}$ cisplatin, was also lower than those of the group treated with cisplatin alone (Figure 5A-C). We also observed the expression of stemness-related proteins using Western blot analysis. Pretreatment with $0.05 \mu \mathrm{M} O$-acetyl RT could reduce the expression of the Nanog $\left(F_{3,8}=6.624, p=0.0496\right)$ and CD44 $\left(F_{3,8}=12.84, p=0.0161\right)$ but the results were not significantly different from those of the group pretreated with $O$-acetyl RT and the group treated with cisplatin alone (Figure 5D,E). In addition, pretreatment with $O$-acetyl RT could also significantly decrease the phosphorylation of $\operatorname{AKT}\left(F_{3,8}=269.3, p<0.0001\right)$, a critical gene related to survival and stemness, whereas total AKT was not changed in comparison to that of cisplatin used alone. Previous results have suggested that cisplatin increased $\mathrm{CD}_{133^{+}}$cells subpopulation in NSCLC cells, which is a responsible for drug resistance [12]. Thus, we observed the effect of $O$-acetyl RT on the number of $\mathrm{CD}_{133^{+}}$cells subpopulation in NSCLC using flow cytometry. As shown in Figure 5F, the CD133+ cells subpopulation was increased in $\mathrm{H} 292$ cells treated with cisplatin alone, while pretreatment with $O$-acetyl RT was able to reduce the number of $\mathrm{CD} 133^{+}$cells subpopulation $\left(F_{3,8}=56.3, p<0.0001\right)$. These results indicate that pretreatment with $\mathrm{O}$-acetyl RT significantly reverses cisplatin-induced $\mathrm{CD} 133^{+}$cells subpopulation in $\mathrm{H} 292$ cells. 
A $O$-acetyl RT $(\mu \mathrm{M})$ Cisplatin $(\mu \mathrm{M}) \quad 0$
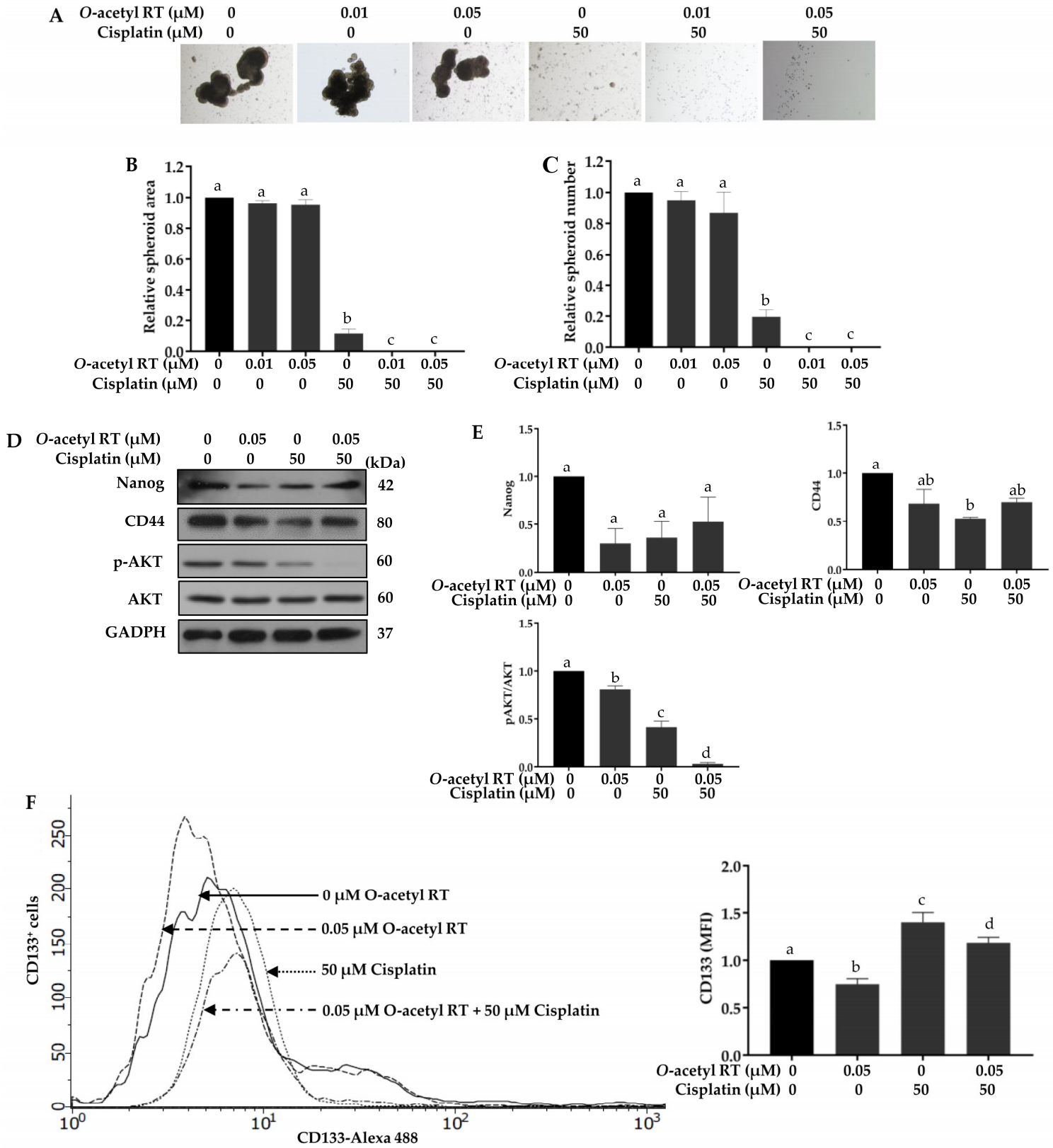

Figure 5. Pretreatment with $O$-acetyl RT reduces the cisplatin-induced enrichment of $\mathrm{CD} 133^{+}$cells. After treatment with 0.01 and $0.05 \mu \mathrm{M}$ of $O$-acetyl RT for $24 \mathrm{~h}$, following treatment with $50 \mu \mathrm{M}$ cisplatin, $\mathrm{H} 292$ cells were suspended and subjected to spheroid formation assay. (A) Spheroids at day 7 were determined by phase-contrast microscopy, and $(\mathbf{B}, \mathbf{C})$ the spheroid number and area were quantified. (D) The expression levels of Nanog, CD44, p-AKT, total AKT, and p53 in H292 cells treated with $0.05 \mu \mathrm{M}$ of $\mathrm{O}$-acetyl RT for $24 \mathrm{~h}$ prior to treatment with $50 \mu \mathrm{M}$ of cisplatin were determined using Western blotting, and (E) the relative expression was assessed using densitometry. (F) The CD133 ${ }^{+}$cells were measured by flow cytometry. Data represent the mean $\pm \operatorname{SD}(n=3)$. Bars labeled with different letters $(\mathrm{a}, \mathrm{b}, \mathrm{c}, \mathrm{d})$ are significantly different at $p<0.05$.

\section{Discussion}

5-O-acetyl-renieramycin $\mathrm{T}$ is a derivative of renieramycin $\mathrm{T}$, which was isolated from the blue sponge Xestospongia sp. found in the seas around Thailand [24] and the Philippines [15,19]. A previous study reported that this synthetic derivative possesses cytotoxicity to many human cancer cell lines, including human colon carcinoma (HCT116), human ductal breast epithelial tumor (T47D), human 
pancreatic adenocarcinoma (AsPC1), and human lung carcinoma (QG56), for which its $\mathrm{IC}_{50}$ at $96 \mathrm{~h}$ ranges from 0.01 to $0.12 \mu \mathrm{M}$ [14]. In this study, we determined the cytotoxicity effect of $O$-acetyl RT on NSCLC cells, H292, A549, and H23 cells. H292 cells were more sensitive to O-acetyl RT than A549 and $\mathrm{H} 23$ cells. Our data indicated that $O$-acetyl-RT has a strong cytotoxic effect on human H292 cell, with an $\mathrm{IC}_{50}$ at $24 \mathrm{~h}$ of $0.66 \mu \mathrm{M}$. Moreover, $\mathrm{O}$-acetyl RT can also induce p53-dependent apoptosis in $\mathrm{H} 292$ cells (Figure 2.). The tumor suppressor p53 is a transcription factor that regulates numerous genes associated with cell cycle arrest, DNA repair, and apoptosis [32]. p53 is activated by various stress stimuli, such as irradiation and DNA damage [33]. The exposure of H292 cells to $O$-acetyl RT $(0-5 \mu \mathrm{M})$ for $24 \mathrm{~h}$ caused a dose-dependent increase in p53 protein level. O-acetyl RT at concentrations $\geq 0.1 \mu \mathrm{M}$ was sufficient to activate the induction of p53 and apoptosis in $\mathrm{H} 292$ cells. Treatment with $O$-acetyl RT at $0.05 \mu \mathrm{M}$ for $24 \mathrm{~h}$ increased p53 protein levels but did not induce apoptosis in H292 cells (Figure 2). Moreover, the expression levels of p53 induced by this concentration were decreased to basal levels after incubation with the medium without cisplatin for $24 \mathrm{~h}$ (Figure $4 \mathrm{~F}, \mathrm{G}$ ).

Cisplatin has been widely used as a chemotherapeutic drug to treat various types of cancer, including NSCLC [3,34]. However, its anti-cancer efficacy is limited due to its side effects and resistance [35]. Cisplatin resistance is contributed by various mechanisms, including reduced intracellular cisplatin accumulation, increased DNA damage repair, increased anti-apoptotic BCL2 levels, and an inactivated apoptotic-related pathway [36]. Accumulating data has indicated that cisplatin induces apoptosis via causing DNA damage, which triggers activation of the p53 protein [37-39]. Herein, cisplatin induced p53-dependent apoptosis and, of note, its efficiency was increased by O-acetyl RT. However, the expression levels of p53 were not significantly different between treatment with cisplatin alone and pre-treatment with $O$-acetyl RT at $0.05 \mu \mathrm{M}$. This result suggests that $O$-acetyl RT sensitized $\mathrm{H} 292$ cells to cisplatin-induced apoptosis in a p53-independent manner. In addition to p53, it has been reported that the ERK signaling pathway can be activated by cisplatin and is a key pathway of p53-dependent apoptosis induced by cisplatin in many cancer cells, including lung cancer cells [29,40,41]. Nevertheless, the ERK pathway is activated in various types of cancers, which activates cancer growth, angiogenesis, and invasion, and suppresses apoptosis [42]. The present study showed that $O$-acetyl RT increased cisplatin-induced ERK activation. Thus, $\mathrm{O}$-acetyl RT sensitized $\mathrm{H} 292$ cells to cisplatin through inducing p53-mediated apoptosis via activating the ERK pathway (Figure 4).

The BCL-2 family of proteins, including anti-apoptotic BCL-2 and pro-apoptotic BAX, are critical regulators of the mitochondrial apoptotic pathway and they have been associated with a more aggressive treatment and drug resistance in cancer chemotherapy [43-45]. In addition, BCL-2 has been reported as a target gene for many signaling pathways, including the ERK pathway [46-48]. The present results indicated that the treatment of cisplatin increased the phosphorylation of ERK proteins, which downregulated the downstream anti-apoptotic BCL-2 protein and upregulated the pro-apoptotic BAX protein in $\mathrm{H} 292$ cells. With a change of balance of BCL-2 and BAX, cisplatin increased apoptosis in $\mathrm{H} 292$ cells and O-acetyl RT could promote its efficiency.

Previous studies have reported that CSCs drive cancer dissemination and relapse [4,49]. Herein, our results indicated that $O$-acetyl-RT suppressed CSCs by the reduction of Nanog and CD44 expression and the number of $\mathrm{CD}_{133^{+}}$cells via an AKT-dependent pathway (Figure 3). Nanog is a transcription factor that is responsible for the maintenance of self-renewal and pluripotency in cancer stem cells under regulation by the AKT pathway [50,51]. It has been reported that a high expression of Nanog can induce CSC-like phenotypes in lung cancer [52]. CD44 and CD133 have been reported as cancer stem cell markers in lung cancer [53-55].

Proliferation and maintenance of CSCs is regulated by other signaling pathways including Wnt, Notch, Hedgehog, TGF $\beta$, STAT3 and PI3K/AKT $[56,57]$. Many studies have shown that AKT is a critical signal that promotes drug resistance and maintains cancer stem-like cell in various cancers including lung cancer $[50,58]$. Activation of AKT can occur through phosphatidylinositol 3-kinases (PI3Ks) that regulate many cellular processes, including cell growth and survival, via receptor tyrosine kinases [59]. Moreover, it has been demonstrated that the inhibition of Akt pathway could suppress the 
expression of CD133 and CD44 [12,13]. CD133 and CD44 often serve as important stemness markers in NSCLC [53,60]. A recent study indicated that the pluripotency genes (OCT4, SOX2, and NANOG) were expressed in CD44+ cells which are more resistant to cisplatin treatment than CD44- cells [54]. CSCs are also believed to play a role in chemotherapeutic resistance [8]. Growing evidence suggests that cisplatin treatment could induce the expression of CSC markers in NSCLC cells [6,61]. It has been reported that cisplatin-resistant $\mathrm{CD} 133^{+}$cells with a self-renewal property, chemoresistance, and a high tumorigenic capability were observed in NSCLC cell lines and in in vivo xenograft models [62]. The inhibition of CD133 expression diminished stemness properties, increased apoptosis via the regulation of BCL-2 and BAX, and increased chemoradiosensitivity in liver cancer stem cells [63]. Interestingly, our data indicated that $O$-acetyl RT could reduce the cisplatin-induced $\mathrm{CD}_{13}{ }^{+}$cell subpopulation in $\mathrm{H} 292$ cells (Figure 5).

\section{Materials and Methods}

\subsection{Reagents and Antibodies}

Dulbecco's Modified Eagle's Medium (DMEM) medium, Roswell Park Memorial Institute (RPMI) 1640 medium, fetal bovine serum (FBS), penicillin/streptomycin, L-glutamine, phosphate-buffered saline (PBS) and trypsin-EDTA were obtained from Gibco (Grand Island, NY, USA). 3-(4,5-dimethylthiazol-2-yl)-2,5-diphenyltetrazoliumbromide (MTT), dimethyl sulfoxide (DMSO), Hoechst33342, propidium iodide (PI), cisplatin, doxorubicin and bovine serum albumin (BSA) were obtained from Sigma-Aldrich, Co. (St. Louis, MO, USA). The following primary antibodies, caspase-9 (\#9502), caspase-3 (\#9662), p53 (\#9282), BCL-2 (\#4223), BAX (\#5023), AKT (\#9272), phosphorylated AKT (\#4060), ERK (\#4695), phosphorylated ERK (\#4370), Nanog (\#4903), CD44 (\#9502), GADPH (\#5174) and $\beta$-actin (\#4970), were obtained from Cell Signaling Technology (Danvers, MA, USA). CD133 (\#CA1217) was obtained from Cell Applications (San Diego, CA, USA). The respective secondary antibodies, anti-rabbit IgG (\#7074) and anti-mouse (\#7076), were obtained from Cell Signaling Technology (Danvers, MA, USA).

\subsection{Preparation of $O-A c e t y l ~ R T$}

The Thai blue sponge Xestospongia sp. was collected by scuba diving at a depth of 3-5 $\mathrm{m}$ in the vicinity of Sichang Island, Chonburi Province, Thailand, in October 2016 with the assistance of the Aquatic Resources Research Institute, Chulalongkorn University. The fresh sponge was identified based on the light bluish-gray color, bulbous surface lobes, numerous and moderate size of oscules and easily crumble texture [16]. The collected sponge was kept frozen at $-20^{\circ} \mathrm{C}$ until used.

The collected blue sponge was homogenized and suspended in the phosphate buffer solution ( $\mathrm{pH} 7$ ). Then, a solution of $10 \%$ potassium cyanide $(\mathrm{KCN})$ in the phosphate buffer solution $(\mathrm{pH} 7)$ was added dropwise to the suspension until the overall $\mathrm{KCN}$ concentration reached $10 \mathrm{mM}$ [16]. Thereafter, the mixture was macerated for $48 \mathrm{~h}$ with methanol. The extract was filtered and the filtrate was concentrated under reduced pressure to obtain the aqueous methanolic solution. The combined aqueous methanolic solution was partitioned with hexane and ethyl acetate, consecutively. Then, the volatile solvent is removed to give a crude residue. The residue was subjected to silica gel chromatography using the gradient solvent mixture of hexane, ethyl acetate, and methanol to furnish renieramycin $\mathrm{T}$ as amorphous powder.

The naturally produced renieramycin $\mathrm{T}$ was employed as a synthetic precursor for chemical modification to yield $O$-acetyl RT by esterification. Renieramycin T ( $10.2 \mathrm{mg}, 0.018 \mathrm{mmol}$ ) was dissolved in dry pyridine $(1.0 \mathrm{~mL})$. Acetic anhydride $(2.5 \mu \mathrm{L}, 0.027 \mathrm{mmol})$ was added to the reaction mixture, which was then stirred at room temperature $\left(25^{\circ} \mathrm{C}\right)$ under an argon atmosphere for $3 \mathrm{~h}$ (Figure 1 ). Then, the reaction was quenched by the addition of water $(5 \mathrm{~mL})$ and extracted with $\mathrm{CH}_{2} \mathrm{Cl}_{2}(10 \mathrm{~mL}, 3$ times). The organic layers were combined, washed with brine $(30 \mathrm{~mL})$, dried over anhydrous $\mathrm{Na}_{2} \mathrm{SO}_{4}$, filtered and concentrated under reduced pressure to obtain a residue. The crude product was purified 
by flash chromatography using silica gel and a mixture of hexanes:EtOAc (4:1) solution as stationary phase and mobile phase, respectively to furnish $O$-acetyl RT $(8.1 \mathrm{mg}, 74 \%)$ as a yellow amorphous solid. The spectroscopic data of $O$-acetyl RT was matched with the previous report [23].

\subsection{Preparation of O-Acetyl RT and Cisplatin Stock Solution}

$\mathrm{O}$-acetyl RT was prepared in DMSO and was further diluted in a complete medium to the desired concentrations. The final concentration of DMSO in each treatment was less than $0.1 \%$ which showed no signs of cytotoxicity. Cisplatin was dissolved in $0.9 \%$ sodium chloride $(\mathrm{NaCl})$ and was diluted in complete medium to provide the indicated working concentrations. The solution was aliquoted and stored at $-20^{\circ} \mathrm{C}$ until further use.

\subsection{Cell Lines and Culture}

Human non-small cell lung cancer (NSCLC) cell lines, H292, A549 and H23 cells were obtained from the American Type Culture Collection (Manassas, VA, USA). H292 and H23 cells were cultured in RPMI 1640 medium. A549 cells were cultured in DMEM medium. The medium was supplemented with $10 \%$ FBS, $2 \mathrm{mM} \mathrm{L}$-glutamine and 100 units $/ \mathrm{ml}$ of each penicillin and streptomycin at $37^{\circ} \mathrm{C}$ with $5 \% \mathrm{CO}_{2}$ in a humidified incubator.

\subsection{Cell Viability Assay}

Cell viability inhibition effect of $O$-acetyl RT on NSCLC cells was determined by MTT assay. In brief, cells were seeded into 96-well plate at $1 \times 10^{4}$ cells/well, allowed to adhere overnight and then treated with different concentration of $O$-acetyl RT $(0,0.01,0.05,0.1,1,5,10,25 \mu \mathrm{M})$ for $24 \mathrm{~h}$. After that, $100 \mu \mathrm{L}$ of MTT solution $(400 \mu \mathrm{g} / \mathrm{ml})$ was added, incubated for another $4 \mathrm{~h}$ at $37^{\circ} \mathrm{C}$. The formazan crystal product was dissolved in $100 \mu \mathrm{L}$ of DMSO. The optical density was measured at $570 \mathrm{~nm}$ using a microplate reader (Anthros, Durham, NC, USA). For O-acetyl RT sensitization in H292 cells, the cells were exposed to $O$-acetyl RT for $24 \mathrm{~h}$, and then after washout of $O$-acetyl RT, cells were incubated in medium with or without cisplatin $(50 \mu \mathrm{M})$ for an additional $24 \mathrm{~h}$.

\subsection{Colony Formation Assay}

$\mathrm{H} 292$ cells pre-treated with $\mathrm{O}$-acetyl RT at non-toxic concentration $(0,0.01$ and $0.05 \mu \mathrm{M})$ for $24 \mathrm{~h}$ were seeded in 24 well plates at a density of 100 cells/well and incubated for 7 days. The colony was fixed with methanol at $4{ }^{\circ} \mathrm{C}$ for $15 \mathrm{~min}$ and stained with $0.1 \%$ crystal violet for $15 \mathrm{~min}$. Colony formation was assessed using a phase-contrast microscope (Olympus IX5, Tokyo, Japan) equipped with a DP70 digital camera system (Olympus, Tokyo, Japan).

\subsection{Spheroid Formation Assay}

$\mathrm{H} 292$ cells pretreated with 0.01 or $0.05 \mu \mathrm{M}$ O-acetyl RT, followed by incubation in medium with or without $50 \mu \mathrm{M}$ cisplatin, were cultured in serum-free medium in 24-well ultralow attachment plates at a cell density of 2500 cells/well. After 7 days, the spheroids were determined using phase-contrast microscopy. The relative spheroid number and area were calculated compared with those of the non-treated cells.

\subsection{Nuclear Staining Assay}

Apoptotic cell death was determined by nuclear staining with a Hoechst 33342 and PI. After being treated with the indicated concentration, $\mathrm{H} 292$ cells were stained with $10 \mu \mathrm{g} / \mathrm{mL}$ Hoechst 33342 for $15 \mathrm{~min}$ at $37^{\circ} \mathrm{C}$ and then stained with $5 \mu \mathrm{g} / \mathrm{mL}$ PI. Cells were imaged randomly using the fluorescent microscope (Olympus IX5, Tokyo, Japan). Apoptotic cells with nuclear condensation and DNA fragmentation were analyzed and expressed as a percentage of apoptotic cells. 


\subsection{Annexin $V$ and Propidium Iodide Apoptosis Assay}

After treatment with O-acetyl RT, H292 cells were collected and washed in cold PBS, pH 7.4. The cells were then dispersed in binding buffer containing annexin V-FITC and PI as recommended in the manufacturer's instructions (ImmunoTools, Friesoythe, Germany). Live, apoptotic and necrotic cells were determined using Guava easyCyte flow cytometer (EMD Millipore, Hayward, CA, USA).

\subsection{Western Blot Analysis}

After O-acetyl RT treatment, H292 cells were incubated with RIPA lysis buffer supplemented with protease inhibitor cocktail (Roche diagnostics, Indianapolis, IN, USA) for $1 \mathrm{~h}$ on ice. The extracted proteins $(50 \mu \mathrm{g})$ were separated by sodium dodecyl sulfate polyacrylamide gel electrophoresis (SDS-PAGE) and further transferred to $0.45 \mu \mathrm{m}$ nitrocellulose membranes (Bio-Rad laboratories, Hercules, CA, USA). The membranes were blocked in Tris-buffer saline containing $0.1 \%$ Tween 20 and $5 \%$ non-fat dry milk for $1 \mathrm{~h}$ at room temperature and incubated with the appropriate primary antibodies at $4{ }^{\circ} \mathrm{C}$ overnight. The membranes were further incubated with horseradish peroxidase (HRP)-conjugated secondary antibodies for $2 \mathrm{~h}$ at room temperature. The membranes were detected using an enhancement chemiluminescent detection system (Supersignal West Pico, Pierce, Rockford, IL, USA) and subsequently exposed to X-ray film. The protein band was analyzed using ImageJ software (version 1.52, National Institutes of Health, Bethesda, MD, USA).

\subsection{Flow Cytometry Analysis}

To determine CD133 expression by flow cytometry, H292 cells treated with O-acetyl RT were trypsinized and incubated in PBS supplemented with 3\% BSA for 30 min on ice. After that, cells were incubated with an anti-CD133 antibody for $1 \mathrm{~h}$ at $4{ }^{\circ} \mathrm{C}$. The cells were then incubated with an Alexa488-conjugated secondary antibody (Catalog no. A11037, Invitrogen, Eugene, OR, USA) for $30 \mathrm{~min}$ at $4{ }^{\circ} \mathrm{C}$ in the dark and washed again before analysis using Guava easyCyte flow cytometer (EMD Millipore, Hayward, CA, USA).

\subsection{Statistical Analysis}

All data from at least three independent experiment are expressed as mean \pm standard deviation (SD). Statistical differences between multiple groups were analyzed using analysis of variance (ANOVA), followed by Turkey's post-hoc test for individual comparisons at the $p<0.05$ significance level.

\section{Conclusions}

Our results provide novel and significant data indicating that $O$-acetyl $\mathrm{RT}$ is able to induce apoptosis and suppress the expression of CSC markers in H292 cells. We also found that O-acetyl RT had the ability to increase cisplatin-induced apoptosis and to decrease the number of cisplatin-induced $\mathrm{CD}_{133^{+}}$cells. These results provide novel and significant data indicating that $O$-acetyl RT might be a promising candidate as a sensitizer in cancer chemotherapy for reducing resistance and suppressing tumor progression.

Author Contributions: Conceptualization, P.C.; Methodology, W.C., S.C., K.S., N.S. and P.C. Formal analysis, W.C. and P.C.; Investigation, W.C, S.C. and P.C.; Writing-original draft preparation, W.C. and S.C. P.C.; Writing-review and editing, K.S., N.S. and P.C.; Funding acquisition, P.C.; Supervision, P.C.

Funding: This research was supported by the Ratchadaphiseksompot Fund for Postdoctoral Fellowship, Chulalongkorn University to W.C. and the Thailand Research Fund (RSA6180036) to P.C. The chemical modification methodology was supported by JSPS KAKENHI Grant Number JP18K06561 of N.S.

Acknowledgments: The authors would like to thank the Cell-based Drug and Health Products Development Research Unit, Chulalongkorn University. 
Conflicts of Interest: The authors declare that there are no conflicts of interest in regard to this study. The authors alone are responsible for the content and writing of this article.

\section{References}

1. Molinski, T.F.; Dalisay, D.S.; Lievens, S.L.; Saludes, J.P. Drug development from marine natural products. Nat. Rev. Drug Discov. 2009, 8, 69-85. [CrossRef] [PubMed]

2. Cragg, G.M.; Grothaus, P.G.; Newman, D.J. Impact of natural products on developing new anti-cancer agents. Chem. Rev. 2009, 109, 3012-3043. [CrossRef] [PubMed]

3. Moharil, R.B.; Dive, A.; Khandekar, S.; Bodhade, A. Cancer stem cells: An insight. J. Oral Maxillofac. Pathol. 2017, 21, 463. [CrossRef] [PubMed]

4. Ayob, A.Z.; Ramasamy, T.S. Cancer stem cells as key drivers of tumour progression. J. Biomed. Sci. 2018, 25, 20. [CrossRef] [PubMed]

5. Koren, A.; Motaln, H.; Cufer, T. Lung cancer stem cells: A biological and clinical perspective. Cell Oncol. (Dordr) 2013, 36, 265-275. [CrossRef] [PubMed]

6. Wang, L.; Liu, X.; Ren, Y.; Zhang, J.; Chen, J.; Zhou, W.; Guo, W.; Wang, X.; Chen, H.; Li, M.; et al. Cisplatin-enriching cancer stem cells confer multidrug resistance in non-small cell lung cancer via enhancing TRIB1/HDAC activity. Cell Death Dis. 2017, 8, e2746. [CrossRef]

7. Levina, V.; Marrangoni, A.M.; DeMarco, R.; Gorelik, E.; Lokshin, A.E. Drug-selected human lung cancer stem cells: Cytokine network, tumorigenic and metastatic properties. PLoS ONE 2008, 3, e3077. [CrossRef]

8. MacDonagh, L.; Gray, S.G.; Breen, E.; Cuffe, S.; Finn, S.P.; O’Byrne, K.J.; Barr, M.P. Lung cancer stem cells: The root of resistance. Cancer Lett. 2016, 372, 147-156. [CrossRef]

9. Wang, Y.; Jiang, M.; Du, C.; Yu, Y.; Liu, Y.; Li, M.; Luo, F. Utilization of lung cancer cell lines for the study of lung cancer stem cells (Review). Oncol. Lett. 2018, 15, 6791-6798. [CrossRef]

10. Salnikov, A.V.; Gladkich, J.; Moldenhauer, G.; Volm, M.; Mattern, J.; Herr, I. CD133 is indicative for a resistance phenotype but does not represent a prognostic marker for survival of non-small cell lung cancer patients. Int. J. Cancer 2010, 126, 950-958. [CrossRef]

11. Liu, Y.-P.; Yang, C.-J.; Huang, M.-S.; Yeh, C.-T.; Wu, A.T.H.; Lee, Y.-C.; Lai, T.-C.; Lee, C.-H.; Hsiao, Y.-W.; $\mathrm{Lu}$, J.; et al. Cisplatin selects for multidrug-resistant $\mathrm{CD} 133^{+}$cells in lung adenocarcinoma by activating Notch signaling. Cancer Res. 2013, 73, 406-416. [CrossRef] [PubMed]

12. Li, J.; Zhou, B.P. Activation of $\beta$-catenin and Akt pathways by Twist are critical for the maintenance of EMT associated cancer stem cell-like characters. BMC Cancer 2011, 11, 49. [CrossRef] [PubMed]

13. Wang, Y.K.; Zhu, Y.L.; Qiu, F.M.; Zhang, T.; Chen, Z.G.; Zheng, S.; Huang, J. Activation of Akt and MAPK pathways enhances the tumorigenicity of $\mathrm{CD} 133^{+}$primary colon cancer cells. Carcinogenesis 2010, 31, 1376-1380. [CrossRef] [PubMed]

14. Scott, J.D.; Williams, R.M. Chemistry and biology of the tetrahydroisoquinoline antitumor antibiotics. Chem. Rev. 2002, 102, 1669-1730. [CrossRef] [PubMed]

15. Edrada, R.A.; Proksch, P.; Wray, V.; Christ, R.; Witte, L.; Van Soest, R.W.M. Bioactive isoquinoline quinone from an undescribed Philippine marine sponge of the genus Xestospongia. J. Nat. Prod. 1996, 59, 973-976. [CrossRef]

16. Suwanborirux, K.; Amnuoypol, S.; Plubrukarn, A.; Pummangura, S.; Kubo, A.; Tanaka, C.; Saito, N. Chemistry of renieramycins. Part 3. Isolation and structure of stabilized renieramycin type derivatives possessing antitumor activity from Thai sponge Xestospongia species, pretreated with potassium cyanide. J. Nat. Prod. 2003, 66, 1441-1446. [CrossRef] [PubMed]

17. Amnuoypol, S.; Suwanborirux, K.; Pummangura, S.; Kubo, A.; Tanaka, C.; Saito, N. Chemistry of renieramycins. Part 5. Structure elucidation of renieramycin-type derivatives $\mathrm{O}, \mathrm{Q}, \mathrm{R}$, and $\mathrm{S}$ from Thai marine sponge Xestospongia species pretreated with potassium cyanide. J. Nat. Prod. 2004, 67, 1023-1028. [CrossRef] [PubMed]

18. Chamni, S.; Sirimangkalakitti, N.; Chanvorachote, P.; Saito, N.; Suwanborirux, K. Chemistry of renieramycins. 17. A new generation of renieramycins: Hydroquinone 5-O-monoester analogues of renieramycin $\mathrm{M}$ as potential cytotoxic agents against non-small-cell lung cancer cells. J. Nat. Prod. 2017, 80, 1541-1547. [CrossRef] [PubMed] 
19. Tatsukawa, M.; Punzalan, L.L.C.; Magpantay, H.D.S.; Villaseñor, I.M.; Concepcion, G.P.; Suwanborirux, K.; Yokoya, M.; Saito, N. Chemistry of renieramycins. Part 13: Isolation and structure of stabilized renieramycin type derivatives, renieramycins $\mathrm{W}-\mathrm{Y}$, from Philippine blue sponge Xestospongia sp., pretreated with potassium cyanide. Tetrahedron 2012, 68, 7422-7428. [CrossRef]

20. Singh, I.P.; Shah, P. Tetrahydroisoquinolines in therapeutics: A patent review (2010-2015). Expert Opin. Ther. Pat. 2017, 27, 17-36. [CrossRef]

21. Yokoya, M.; Toyoshima, R.; Suzuki, T.; Le, V.H.; Williams, R.M.; Saito, N. Stereoselective total synthesis of (-)-renieramycin T. J. Org. Chem. 2016, 81, 4039-4047. [CrossRef] [PubMed]

22. Kimura, S.; Saito, N. Construction of the pentacyclic core and formal total synthesis of (rac)-renieramycin T. ChemistryOpen 2018, 7, 764-771. [CrossRef] [PubMed]

23. US Food and Drug Administration. FDA Approves New Therapy for Certain Types of Advanced Soft Tissue Sarcoma. Available online: https:/ / www.accessdata.fda.gov/drugsatfda_docs/label/2015/207953s000lbl. pdf (accessed on 28 January 2019).

24. Daikuhara, N.; Tada, Y.; Yamaki, S.; Charupant, K.; Amnuoypol, S.; Suwanborirux, K.; Saito, N. Chemistry of renieramycins. Part 7: Renieramycins $\mathrm{T}$ and aU, novel renieramycin-ecteinascidin hybrid marine natural products from Thai sponge Xestospongia sp. Tetrahedron Lett. 2009, 50, 4276-4278. [CrossRef]

25. Charupant, K.; Daikuhara, N.; Saito, E.; Amnuoypol, S.; Suwanborirux, K.; Owa, T.; Saito, N. Chemistry of renieramycins. Part 8: Synthesis and cytotoxicity evaluation of renieramycin M-jorunnamycin A analogues. Bioorg. Med. Chem. 2009, 17, 4548-4558. [CrossRef] [PubMed]

26. Johnstone, R.W.; Ruefli, A.A.; Lowe, S.W. Apoptosis: A link between cancer genetics and chemotherapy. Cell 2002, 108, 153-164. [CrossRef]

27. Vazquez, A.; Bond, E.E.; Levine, A.J.; Bond, G.L. The genetics of the p53 pathway, apoptosis and cancer therapy. Nat. Rev. Drug Discov. 2008, 7, 979-987. [CrossRef] [PubMed]

28. Fiandalo, M.V.; Kyprianou, N. Caspase control: Protagonists of cancer cell apoptosis. Exp. Oncol. 2012, 34, 165-175. [PubMed]

29. Wesarg, E.; Hoffarth, S.; Wiewrodt, R.; Kröll, M.; Biesterfeld, S.; Huber, C.; Schuler, M. Targeting BCL-2 family proteins to overcome drug resistance in non-small cell lung cancer. Int. J. Cancer 2007, 121, 2387-2394. [CrossRef]

30. Luanpitpong, S.; Chanvorachote, P. Nitric oxide and aggressive behavior of lung cancer cells. Anticancer Res. 2015, 35, 4585-4592.

31. Wang, X.; Martindale, J.L.; Holbrook, N.J. Requirement for ERK activation in cisplatin-induced apoptosis. J. Biol. Chem. 2000, 275, 39435-39443. [CrossRef]

32. Horn, H.F.; Vousden, K.H. Coping with stress: Multiple ways to activate p53. Oncogene 2007, 26, $1306-1316$. [CrossRef]

33. Pflaum, J.; Schlosser, S.; Müller, M. p53 family and cellular stress responses in cancer. Front. Oncol. 2014, 4, 285. [CrossRef]

34. Dasari, S.; Tchounwou, P.B. Cisplatin in cancer therapy: Molecular mechanisms of action. Eur. J. Pharmacol. 2014, 740, 364-378. [CrossRef]

35. Wang, G.; Reed, E.; Li, Q.Q. Molecular basis of cellular response to cisplatin chemotherapy in non-small cell lung cancer. Oncol. Rep. 2004, 12, 955-965. [CrossRef]

36. Galluzzi, L.; Senovilla, L.; Vitale, I.; Michels, J.; Martins, I.; Kepp, O.; Castedo, M.; Kroemer, G. Molecular mechanisms of cisplatin resistance. Oncogene 2012, 31, 1869-1883. [CrossRef]

37. Guntur, V.P.; Waldrep, J.C.; Guo, J.J.; Selting, K.; Dhand, R. Increasing P53 protein sensitizes non-small cell lung cancer to paclitaxel and cisplatin in vitro. Anticancer Res. 2010, 30, 3557-3564.

38. Yang, M.; Yuan, F.; Li, P.; Chen, Z.; Chen, A.; Li, S.; Hu, C. Interferon regulatory factor 4 binding protein is a novel p53 target gene and suppresses cisplatin-induced apoptosis of breast cancer cells. Mol. Cancer 2012, 11, 54. [CrossRef]

39. Liu, R.; Ji, P.; Liu, B.; Qiao, H.; Wang, X.; Zhou, L.; Deng, T.; Ba, Y. Apigenin enhances the cisplatin cytotoxic effect through p53-modulated apoptosis. Oncol. Lett. 2017, 13, 1024-1030. [CrossRef]

40. Persons, D.L.; Yazlovitskaya, E.M.; Pelling, J.C. Effect of extracellular signal-regulated kinase on p53 accumulation in response to cisplatin. J. Biol. Chem. 2000, 275, 35778-35785. [CrossRef] 
41. Zhang, Z.; Wu, Y.; Liang, H.; Zhang, B.; Zhang, W. MAPK/ERK activation sensitizes MKN-28 cells to cisplatin-induced apoptosis. Cancer Stud. Mol. Med. Open J. 2015, 2, 52-59. [CrossRef]

42. Miyake, M.; Goodison, S.; Lawton, A.; Gomes-Giacoia, E.; Rosser, C.J. Angiogenin promotes tumoral growth and angiogenesis by regulating matrix metallopeptidase-2 expression via the ERK1/2 pathway. Oncogene 2015, 34, 890-901. [CrossRef]

43. Kale, J.; Kutuk, O.; Brito, G.C.; Andrews, T.S.; Leber, B.; Letai, A.; Andrews, D.W. Phosphorylation switches Bax from promoting to inhibiting apoptosis thereby increasing drug resistance. EMBO Rep. 2018, 19, e45235. [CrossRef]

44. Sartorius, U.A.; Krammer, P.H. Upregulation of bcl-2 is involved in the mediation of chemotherapy resistance in human small cell lung cancer cell lines. Int. J. Cancer 2002, 97, 584-592. [CrossRef]

45. Wongvaranon, P.; Pongrakhananon, V.; Chunhacha, P.; Chanvorachote, P. Acquired resistance to chemotherapy in lung cancer cells mediated by prolonged nitric oxide exposure. Anticancer Res. 2013, 33, 5433-5444.

46. Jin, J.; Xiong, Y.; Cen, B. Bcl-2 and Bcl-xL mediate resistance to receptor tyrosine kinase targeted therapy in lung and gastric cancer. Anticancer Drugs 2017, 28, 1141-1149. [CrossRef]

47. Liu, Y.; Yang, Y.; Ye, Y.-C.; Shi, Q.-F.; Chai, K.; Tashiro, S.; Onodera, S.; Ikejima, T. Activation of ERK-p53 and ERK-mediated phosphorylation of Bcl-2 are involved in autophagic cell death induced by the c-Met inhibitor SU11274 in human lung cancer A549 cells. J. Pharmacol. Sci. 2012, 118, 423-432. [CrossRef]

48. Sun, P.-L.; Sasano, H.; Gao, H. Bcl-2 family in non-small cell lung cancer: Its prognostic and therapeutic implications. Pathol. Int. 2017, 67, 121-130. [CrossRef]

49. Lobo, N.A.; Shimono, Y.; Qian, D.; Clarke, M.F. The biology of cancer stem cells. Annu. Rev. Cell Dev. Biol. 2007, 23, 675-699. [CrossRef]

50. Srinual, S.; Chanvorachote, P.; Pongrakhananon, V. Suppression of cancer stem-like phenotypes in NCI-H460 lung cancer cells by vanillin through an Akt-dependent pathway. Int. J. Oncol. 2017, 50, 1341-1351. [CrossRef]

51. Dubrovska, A.; Kim, S.; Salamone, R.J.; Walker, J.R.; Maira, S.-M.; García-Echeverría, C.; Schultz, P.G.; Reddy, V.A. The role of PTEN/Akt/PI3K signaling in the maintenance and viability of prostate cancer stem-like cell populations. PNAS 2009, 106, 268-273. [CrossRef]

52. Shan, J.; Shen, J.; Liu, L.; Xia, F.; Xu, C.; Duan, G.; Xu, Y.; Ma, Q.; Yang, Z.; Zhang, Q.; et al. Nanog regulates self-renewal of cancer stem cells through the insulin-like growth factor pathway in human hepatocellular carcinoma. Hepatology 2012, 56, 1004-1014. [CrossRef]

53. Mizugaki, H.; Sakakibara-Konishi, J.; Kikuchi, J.; Moriya, J.; Hatanaka, K.C.; Kikuchi, E.; Kinoshita, I.; Oizumi, S.; Dosaka-Akita, H.; Matsuno, Y.; et al. CD133 expression: A potential prognostic marker for non-small cell lung cancers. Int. J. Clin. Oncol. 2014, 19, 254-259. [CrossRef]

54. Leung, E.L.-H.; Fiscus, R.R.; Tung, J.W.; Tin, V.P.-C.; Cheng, L.C.; Sihoe, A.D.-L.; Fink, L.M.; Ma, Y.; Wong, M.P. Non-small cell lung cancer cells expressing CD44 are enriched for stem cell-like properties. PLoS ONE 2010, 5, e14062. [CrossRef]

55. Maiuthed, A.; Chantarawong, W.; Chanvorachote, P. Lung cancer stem cells and cancer stem cell-targeting natural compounds. Anticancer Res. 2018, 38, 3797-3809. [CrossRef]

56. Koury, J.; Zhong, L.; Hao, J. Targeting signaling pathways in cancer stem cells for cancer treatment. Stem Cells Int. 2017, 2017, 2925869. [CrossRef]

57. Matsui, W.H. Cancer stem cell signaling pathways. Medicine (Baltimore) 2016, 95, S8-S19. [CrossRef]

58. Phi, L.T.H.; Sari, I.N.; Yang, Y.-G.; Lee, S.-H.; Jun, N.; Kim, K.S.; Lee, Y.K.; Kwon, H.Y. Cancer stem cells (CSCs) in drug resistance and their therapeutic implications in cancer treatment. Stem Cells Int. 2018, 2018, 5416923. [CrossRef]

59. Castellano, E.; Downward, J. RAS Interaction with PI3K. Genes Cancer 2011, 2, 261-274. [CrossRef]

60. Hu, B.; Ma, Y.; Yang, Y.; Zhang, L.; Han, H.; Chen, J. CD44 promotes cell proliferation in non-small cell lung cancer. Oncol. Lett. 2018, 15, 5627-5633. [CrossRef]

61. Barr, M.P.; Gray, S.G.; Hoffmann, A.C.; Hilger, R.A.; Thomale, J.; O’Flaherty, J.D.; Fennell, D.A.; Richard, D.; O'Leary, J.J.; O’Byrne, K.J. Generation and characterisation of cisplatin-resistant non-small cell lung cancer cell lines displaying a stem-like signature. PLoS ONE 2013, 8, e54193. [CrossRef] 
62. Bertolini, G.; Roz, L.; Perego, P.; Tortoreto, M.; Fontanella, E.; Gatti, L.; Pratesi, G.; Fabbri, A.; Andriani, F.; Tinelli, S.; et al. Highly tumorigenic lung cancer $\mathrm{CD}_{133^{+}}$cells display stem-like features and are spared by cisplatin treatment. PNAS 2009, 106, 16281-16286. [CrossRef]

63. Lan, X.; Wu, Y.-Z.; Wang, Y.; Wu, F.-R.; Zang, C.-B.; Tang, C.; Cao, S.; Li, S.L. CD133 silencing inhibits stemness properties and enhances chemoradiosensitivity in CD133-positive liver cancer stem cells. Int. J. Mol. Med. 2013, 31, 315-324. [CrossRef]

2019 by the authors. Licensee MDPI, Basel, Switzerland. This article is an open access article distributed under the terms and conditions of the Creative Commons Attribution (CC BY) license (http://creativecommons.org/licenses/by/4.0/). 